\title{
Eleştirel Perspektiften Marksist Estetik ve Fotoğraf İlişkisi
}

\author{
DOI: $10.26466 /$ opus.865397
}

\author{
Rifat Becerikli* - Ahmet Dönmez ** \\ * Dr. Öğr. Üyesi, Bozok Üniversitesi, İletişim Fakültesi,Radyo, Televizyon ve Sinema Böl.Yozgat/Türkiye \\ E-Posta: rifatbecerikli@bozok.edu.tr \\ ORCID: 0000-0001-6392-8330 \\ ** Dr. Öğr. Üyesi, Çankırı Karatekin Üniversitesi, Sanat, Tasarım ve Mimarlık Fakültesi, Sinema ve , \\ Televizyon Bölümü, Çankır//Türkiye \\ E-Posta: ahmetdonmez@karatekin.edu.tr \\ ORCID: $\underline{0000-0003-1010-3516}$
}

\section{Öz}

Sanat alanında yapılan çalışmalarda en çok üzerine düşünülen kavramlardan biri estetiktir. "Güzel" üzerine düşünme olarak tanımlanabilen estetik birçok filozofun ilgi alanı olmuştur. Çağlar boyunca sanat yapıtının estetik özellikleri, düşünce insanlarının çeşitli yaklaşımlarına göre değerlendirilmiştir. Bu bağlamda, sanat açısından estetik olanın özellikleri tespit edilmeye çalışılmıştır. Bu çaba estetik felsefesinin gelişmesi yönünde büyük katkı sağlamıştır.

Karl Marks ve Friedrich Engels daha çok toplum, ekonomi, politika alanında çalışmaları ile bilinen düşün insanları olmalarının yanında estetik olgusu ile özellikle edebiyat metinleri temelinde ilgilenmişlerdir. Genel olarak sanatçının ve sanatın nasıl bir yaklaşım içinde olması gerektiği hakkındaki düşünürlerin görüşleri, "Marksist Estetik" yaklaşımının temelini oluşturmaktadır. Marksist estetik, bazı sanatçılar ve düşünürler açısından kuramsal bir çıkış noktası olarak görülmektedir. Bu estetiğe dair fikirsel yaklaşımlar sanatçıların eserlerinde izlenebilmektedir.

Marksist estetik çerçevesinde değerlendirilebilecek bir fotoğraf sanatçısı olan Lee Jeffries, özellikle modern, gelişmiş ülkelerdeki evsiz insanların portre fotoğrafları ile tanınmaktadır. Sanatçı, 2019 yılında Evsizler Sergisi (Homeless The Exhibition) adında bir foto-kitap yayınlamıştır. Bu doğrultuda çalışmada, amaçsal örneklemle seçilmiş Lee Jeffries'in portre fotoğrafları, Marksist estetik kavramsallaştırılması üzerinden niteliksel ve teknik olarak Terry Barret'in önerdiği "Biçimsel Analiz" yöntemiyle çözümlenmeye çalışılmıştır. Sonuç olarak Jeffries'in fotoğraflarında, kapitalist sistemin en alt sinıfında olduğu söylenebilecek olan "evsiz" insanlarm konu edinilmesi, bu insanların çıarlarının dolaylı olarak gözetilmesi, fotoğrafın sınıf çatışmaların if̧̧a eden ideolojik bir bilinçlenme aracı olarak kullanılması, fotoğraflardaki mesajın izleyici yorumlamasına açık olması gibi nedenlerden dolayı, sanatçının eserlerinde Marksist estetiğin unsurlarımı kullandığg çıkarımını yapmak mümkündür.

Anahtar Kelimeler: Fotoğraf, Marksist Estetik, Lee Jeffries 


\title{
Relationship between Marxist Aesthetics and Photography from Critical Perspective
}

\begin{abstract}
Aesthetics is one of the most contemplated concepts in the field of art. Aesthetics, which can be defined as reflecting on the "beautiful" has been a pursuit of interest to many philosophers. Over the years, the aesthetic features of a work of art are being evaluated following various approaches of people of thought. In this context, the features of the aesthetic in terms of art continued to steer to determine. These efforts have made a great contribution to the development of aesthetic philosophy.

Karl Marx and Friedrich Engels, besides being well-known thinkers within the fields of society, economy, and politics, also dealt with the aesthetic phenomenon based on literary texts. In general, the views of the thinkers about how the artist and art should approach; form the basis of the "Marxist Aesthetics" approach. Marxist aesthetics is viewed as a theoretical starting point for some artists and thinkers. Intellectual approaches to this aesthetics can be followed in the works of artists.

Lee Jeffries, a photographer who will be discussed within the framework of this approach, is especially known for his portraits of homeless people in modern, developed countries. The artist has published a photo-book called Homeless The Exhibition in 2019. In this context, the portrait photographs of Lee Jeffries, selected via purposeful sampling, are analyzed qualitatively and technically with the "Formal Analysis" method proposed by Terry Barret, through the Marxist aesthetic conceptualization. To elaborate, Jeffries' photographs are involved with the "homeless", who are considered to be in the lowest class of the capitalist system. The indirect observation of their interests, the use of photography as an ideological awareness tool that reveals class conflicts and the message in the photographs are open to audience interpretation. Thus, it is possible to infer that the artist uses the elements of Marxist aesthetics in his works.
\end{abstract}

Keywords: Photograpy, Marxist Aesthetics, Lee Jeffries 


\section{Giriş}

Yüzyıllardır sanat eserlerinin (edebiyat, resim, heykel, müzik vb.) niteliği, estetik kavramı üzerinden tartışla gelmektedir. Sanatta "güzel" üzerine düşünme çabasını işaret eden estetik kavramı, insan var olduğu sürece tartışılmaya ve gelişmeye devam etmektedir. Marksist yaklaşım için sanat bir çeşit üretimdir. Sanatçının eylemi, hiçten bir şey yaratmak değil, önceden hazır olan malzemeyi işlemek ve eser ortaya çıarmaktır (Moran, 2002, s.67). Tarih boyunca her toplum maddi ve manevi evrenini geliştirmek için bir takım üretim etkinliklerinde bulunur. Bu bağlamda insanın üretim gücünü dünyada var olduğu ilk andan itibaren başlatmak mümkündür. "Şüphesiz hayvanlar da üretirler. Arılar, kunduzlar, karıncalar ve başka hayvanlar kendilerine yuva, barınak yaparlar. Ama hayvanlar yalnızca kendilerinin ya da yavrularının dolaysız gereksinmeleri için üretirler; ürünleri tek yanlıdır" (Marks, 2013, s.82). Ancak insan üretimi bazı durumlarda hayvandan ayr1şabilmektedir. Hayvanların içgüdüsel olarak yaşamlarını devam ettirme, hayatta kalma amacıyla üretim eylemlerini gerçekleştirdiği düşünülmektedir. İnsanın üretim etkinlikleri incelendiğinde ise üretimin tek gayesinin sadece hayatta kalma olmadığı görülmektedir. Bilişsel haz, iletişim, eleştiri gibi bazı faktörler de insan üretiminde etkili olabilmektedir. Marksist düşünce yaklaşımının, insanı hayvanlardan ayıran temel yanı, insanların yetenek geliştirebilen ve yeniden üretebilen yaratıklar olmalarıdır (Eagleton, 2009, s. 202-203). Diğer bir ifade ile insan, bilinçli tasarımlarla, estetik yaklaşımı da kapsayan ürünler ortaya çıkarabilmektedir.

İnsanın doğayla olan üretim temelli ilişkisi, doğanın insan algısındaki yerini de şekillendirmektedir. "İnsan ilk olarak nesnel dünyanın işlenmesinde, bir tür varlığı olduğunu gerçekten kanıtlamaktadır. Bu üretim onun etkin türsel hayatıdır. Bu üretim yoluyla ve bu üretim dolayısıyla, doğa insanın kendi eseri ve kendi gerçekliği olarak görünür" (Marks, 2013, s. 82). İnsanın emek temelinde dünyayı değiştirme gücü onun sanat alanındaki yapıtları ile de belirginleşir. İnsan tarihsel süreç içinde amaçlı bir yönelimle dünyayı değiştirme ve dönüştürme gücüne sahip yegâne canlıdır. Bu bağlamda Marks insanın, pratik eylemleriyle kendine ait dünya yarattığını, yaban doğayı işlerken bilinçli bir türsel varlık izlenimi sergilediğini söyler (2013, s. 81). Öte yandan insan bir amaç içerisinde, önceden tasarladığı biçimde yaratıcı üretim yapan bir canlıdır. Marks'a göre "maddi hayatın üre- 
tim tarzı, genel olarak toplumsal, siyasal ve entelektüel hayat sürecini koşullandırır. İnsanların varlı̆̆ını belirleyen şey, bilinçleri değildir; tam tersine, onların bilincini belirleyen, toplumsal varlıklarıdır" (2011, s.9). Aynı şekilde mevcut tarihi, politik ve ekonomik koşullar insan üretimlerini dolayısıyla sanat eserlerini de etkiler. Diğer bir ifade ile sanat yapıtı, ancak, belli bir toplum yapısında ortaya çıkar. Örneğin, destanların oluşabilmesi için, toplumun tanrılar ya da yarı tanrılar tarafından yönetildiğine inandığı köleci toplum aşamasında bulunması gerekir (Timuroğlu, 2013, s.130). Örneğin Yunan mitolojisi yalnızca Yunan sanatının kaynağı değildir; aynı zamanda sanatı besleyen temel unsurları da belirlemiştir (Marks, 2011, s.256). Diğer yandan gündelik yaşam pratikleri de sanatsal üretim açısından önemlidir. Bu bağlamda ilkel toplumların avcılık gereksinimi temelinde mağara resimlerine yöneldikleri de söylenebilir.

İlkel toplulukların yaşam koşulları ve biçimleri şu andakinden oldukça farklıdır. Genellikle kabileler şeklinde yaşayan insanların doğada anlamlandıramadıkları olayların yarattığı gerilimi farklı şekillerde aşmaya çalıştıkları görülmektedir. Bu nedenle de birçok ilkel toplulukta büyünün bir sanat olarak nitelendirildiği veya sanatın büyüyle ilişkilendirildiği görülmektedir (Malinowski, 1998). Sanatın büyü ve sanatçının da büyücü olarak isimlendirildiği ilkel toplumda büyücü, topluluğun beklentilerini büyü gücüyle gerçekleştirmezse, öldürülme tehlikesiyle de yüz yüze kalmaktadır (Fischer, 1990, s.37). Büyücünün toplum üzerindeki güçlü etkisine karşıllk, kendisinden beklenti de yüksek düzeydedir. Toplum düzeninin dışında tek başına yaşamanın düşünülemeyeceği bir ortamda bütün çabalar gibi büyücülük biçimindeki sanat çabası da toplumun bütünlügüne ve yaşama eylemine dönük yapıdadır (Doğan, 1975, s.154). Bu bağlamda sanatçıyı, toplumsal yaşamın sorunlarına çözüm bulmaya veya onları aşmaya çalışan "büyücü" olarak nitelendirmek mümkündür. İlkel dönemde sanatç/büyücü, tanrılarının, totem hayvanlarının vb. sembollerini, figür ve maskelerini yapıp onlarla barışıklığı sağlamaya yardım ederek, topluluğun maddi ve manevi işlerinin düzenli gitmesini amaçlamıştır (Örnek, 1995, s.162). Plehanov, sanatın hayatta bir takım sorunları çözdüğü gibi, bir haz kaynağı işlevi de gördüğünü ileri sürmektedir (Bottomore, 1993, s.474). Bu bakımdan sanat hem toplumsal bir sorunu halleder hem de kişisel bir haz aracıdır. Örneğin dans ederek yağmur duasına çıkan kabileler hem toplumsal olarak su sorununu çözmeye çalışırken, etrafta bir ritm eşliğinde dans ederek ruhsal ola- 
rak da doyuma ulaşmaktadır. Plehanov ilkel topluluklarda dansı çalışma sürecinin (örneğin bir avlanmanın) yeniden taklidi olarak ve icra edilen müzikleri (ritm sayesinde) yapılan işe yardım eden bir öğe olarak yorumlar (Bottomore, 1993, s.474). İlkel sanatlara örnek olarak ateş yakma, tahta ya da taştan aletler yapma, basit evler kurma veya barınak olarak mağaraları tasarımlamak verilebilir (Malinowski, 1992, s.45). Bu tip eylemler ve işlevsellikleri zamanla gelişerek toplumun farklı ihtiyaçlarına cevap vermektedir.

"Üst paleolitikte Aurignac kültür evresinde ortaya çıkan mă̆ara sanatı, teknolojik gelişmeye paralel olarak, doruğa erişir. Sanat biçimlerinde ve anlatımda belirgin bir gelişme vardır. Derin mağaraların ışık görmeyen duvarlarında, renkli hayvan resimleri ve av sahneleri bulunmuştur. Avclar, giyimli, ok ve yay ile donanmış, av hayvanları ise çoğu kez ok veya mırakla yaralı durumda çizilmiştir. Duvarlarda boş yerler olduğu halde, resimlerin üst üste çizilmiş olması, resimlerin dinsel, büyüsel ve törensel bir anlam taşıdığı yönünde yorumlanmaktadır" (Güvenç, 1979, s. 175).

Bu bağlamda bir hayvanın resminin doğru yapılmasının, o hayvanı ele geçirmek için çıkılacak avın başarısını güvence altına aldığı yolunda büyüsel bir inanç vardır (Lukacs, 1981, s. 40). Bunu gerçekleştirecek kişi de mağara duvarını çizen ve boyayan insandır. Bu amaçsallık doğrultusunda duvara çizilen figürlerin benzerlik ilişkisi bir yandan araçsal diğer yandan estetik bir yaklaşım taşımaktadır.

Marks ve Engels, iki düşünür de, insanın estetik duyusunun doğuştan gelmediğini, toplumsal olarak sonradan edilen bir özellik olduğunu vurgulamışlardır (Krylov, 2009, s. 14). İnsanın müzik duyusunu ancak müzik arttırabilir ve müzikten anlamayan biri için en güzel müziğin bile anlamı yoktur (Marks, 2013, s. 117). Herhangi bir alanda gelişme için süreç gerekmektedir. Sanat için de bu durum farklı değildir. Marksist estetik insanın doğumundan itibaren sanat duyusu taşıdı̆̆ını savunan tüm görüşlerin açıkça karşısında yer alır; insandaki sanat yeteneklerinin ve sanat ürünlerinin tarihsel gelişmenin akışı içerisinde oluştuğunu söyler (Lukacs, 1978, s. 173). $\mathrm{Bu}$ açıdan insanın estetik kriterleri de tarihsel süreç ve toplumsal koşulların bir sonucudur. Buna ilkel toplumların yaşam alışkanlıkları ve sanat anlayışları örnek verilebilir. Tarihsel süreçte insan, kendini estetik değerler bakımından da geliştirir. Morawski, Marksist anlayışa göre sanatsal estetiğin, tarihsel/toplumsal değişim ve gelişim çizgisini şöyle açıklamaktadır: 
"ilk önce insan, nesnelerinin yapısını sanatsal olarak şekillendirir ancak bu maddi dünyaya insanca hâkim olma gücünü ifade eder; sonrasında ise nesnesinin yapısı (içsel ölçü, orantı) sanatsal sürecin temel amacı haline gelir; pratik olmayan estetik düşüncenin ilk nüveleridir, sonunda ise insan renk, ses ve şekil gibi belirli özelliklere karşı duyarllık, estetik duyu ve nispeten özerk bilinç geliştirir" (Morawski, 1970, s. 370).

İnsan gelişimiyle paralel olarak sanata dair ilerleme de devam etmektedir. Estetiğe dair bilinç de giderek gelişir ve ilerler. Öte yandan büyüsel gereksinimler, büyüsel uygulama açısından bir önem taşımayan, ama estetik açıdan gerçek değer içeren yapıtların yaratılmasına da yol açar (Lukacs, 1981, s. 24). Eski çağlardan kalan seramik kaplar, vazolar ve benzeri eşyalardaki geometrik motifler bu duruma örnek olarak verilebilir. Toplumsal yaşam dönüşüp maddi ihtiyaçlar değişince büyücünün/sanatçının görev ve sorumlulukları da değişime uğrar. Bu durumu Fischer; modern toplumda, kabiledeki büyücünün görevinin sanatçı, din adamı, hekimlerin ve düşünürlerin arasında paylaşıldığını söylemektedir. Özellikle sanatçı bu yapı içerinde bir sözcü/temsilci olarak kalmıştır (Fischer, 1990, s. 37). Bu bağlamda sanatın ve sanatçının toplumsal alandaki işlevi modern dünyadaki sosyal yaşamda nitelik değiştirse de hala görünürdür. İnsan sanat bağlamında doğanın bir taklitçisi değil, ondan ilhamlanarak öznel ve tekil bir yorumlama ile üretim yapabilen yaratıcı konumundadır. Diğer bir ifade ile Marks için sanat, insanın dünyayı insanlaştırdığı ve onu somut bir biçimde yeniden şekillendirdiği özgün çalışmalardır (King, 1991, s. 324). Böylece dünya, insanın öznel yorumlarıyla ve onun estetik anlayışıyla biçimlenmektir.

\section{Amaç, Yöntem, Örneklem}

$\mathrm{Bu}$ araştırma, fotoğraf sanatçısı olan Lee Jeffries'in portre fotoğraflarının Marksist Estetikle olan ilişkisini ortaya koymayı amaçlamaktadır. Bu hedef doğrultusundan çalışma evreni Lee Jeffries'in "Evsizler" serisine ait portre fotoğraflarıdır. Örneklemi ise sanatçının porte fotoğrafları içinden amaçsal örneklemle seçilmiş üç adet fotoğraf oluşturmuştur. Seçilen örneklem fotoğraflar Niteliksel araştırma yöntemlerinden biri olan Terry Barret'in fotoğraf çözümlemeleri için önerdiği "Biçimsel Analiz" tekniğiyle değerlendirilmiştir. Barret, Biçimsel analizi "betimleme ve yorumlamanın bir kombinasyo- 
nu" (Barret, 2012, s. 61) olarak tanımlamaktadır. Bu analize göre bir fotoğrafın biçimsel özellikleri betimlenirken teknik değerler, odak noktası, kontrast ve benzeri kompozisyona dair bileşenler öne çıkarken, yorumlama kısmında ise teorik fikirler belirtilmektedir (Barret, 2012, s. 62). Bu doğrultuda çalışmada teorik kısımda açıklanan Marksist Estetik yaklaşımı bağlamında Jeffries' in "Evsizler" fotoğrafları analiz edilmeye çalışılmıştır.

\section{Marksist Estetik Yaklaşımı}

Marks ve Engels edebiyat hakkındaki bazı görüşleri dışında sanat ve estetik alanına dair özel metinler yazmamıştır. Diğer yandan Marksizm büyük bir anlatı olarak ele alındığında estetik dâhil hayatın bütününü açıklama iddiasinda olan bir düşünce sistemidir (Belge, 1989, s. 28). Bu bağlamda Marksizm'in genel görüşleri bağlamında birçok düşün insanı estetik bir teori ortaya koymaya çalısır. Phelenov, Eagleton, Lukacs, Brecht, Benjamin, Adorno gibi eleştirel araştırmacıların özgül yaklaşımları Marksist estetik içinde temellenebilecek sistematik yaklaşımları belirtmektedir. Bu düşünürler estetik konusunda Marksist bakışın temel niteliklerini oluşturmaya çalışmaktadır.

Söz konusu sanat olduğunda ortaya çıkan eser kadar, onu meydana getirenin de üzerinde düşünmek gerekmektedir. Marksist estetiğe göre toplumun ekonomi-politiği dışında onu amaçlı eylem ile üreten insan da eser kadar değerlidir. Gombrich, "Sanat diye bir şey yoktur aslında. Yalnızca sanatçılar vardır. Bir zamanlar bazı adamlar renkli toprakla bir mağaranın duvarına kabaca bizon resimleri çiziktiriyordu; bugün de bazıları boya satın alıp duvar ya da tahta perdeleri resimliyor ve daha birçok başka şeyler üretiyorlar" (Gombrich, 2010, s. 16) dediğinde, tam da sanatçının yaratıcı önemini vurguladığı gibi sanatın toplumsal ve tarihsel olarak değişimine de odaklanmaktadır. Sanat eseri denen şey doğayı, yaşamı sanatçının yorumlamasıdır (Tunalı, 1976, s. 99). Sanatçının bu yorumlamadaki konumu kendi sanat anlayışını da ortaya çıkarmaktadır. Diğer bir ifade ile bir sanatçı etrafında gördüğü kuşları en gerçekçi şekilde fotoğraflayabilir. Diğeri ise dağ keçilerinin vurulmasını, nesli tükenme tehlikesi temelinde resminde eleştirebilir. Marksist estetik de sanat eserini mevcut toplumsal yaşamdaki ekonomi-politik ve tarihi olgularla ilişkisi temelinde değerlendirir. Bu bağlamda Marksist estetik temel olarak şöyle de tanımlanabilir: "insanların dünya- 
yı dönüştürme faaliyetinin bir parçası olan sanatın özü ve gelişme kanunları ile sanatın sosyal dönüşüm de oynadığı rolü araştıran bilim"dir (Akdere, 2010, s. 157). Diğer taraftan estetik, doğrulanabilir ya da yanlışlanabilir önermelerle sistematik bir sinıflama ölçütüne dayandırılabildiği ölçüde materyalist anlayışa yaklaşacaktır. Aynı şekilde sanatın ve sanatçının toplumsal değişimde başat rol oynadığı da vurgulanmaktadır.

Marksist estetik için yaşamdaki "gerçek" in sergilenmesi önem taşır. Doğal gerçeklik, insanın dışında varlığını sürdüren gerçekliktir. Öte yandan, estetik gerçeklik, insanı (sanatçıyı/özneyi) temel alan gerçekliktir (Tunalı, 1976, s. 102). Öznenin perspektifi sanat açısından belirleyicidir. Buradaki insana dayalı bireysel yaratıcılık veya bakış, sanatçının toplumsalcı düşünceye ters düştüğü anlamına gelmez (Timuroğlu, 2013, s. 134). Bu bağlamda Marksist estetik temelinde, sanat eserinin temeli olan gerçeklik, insanın dişında var olan bir gerçeklik değildir; insana, topluma dayalı bir gerçekliktir (Tunalı, 1976, s. 102-103). Yaşamın içindeki insanın algıladığı, farkında olduğu verilerdir. Aynı şekilde Marksist estetik sanatın sübjektif olduğunu belirtir ama bu sübjektiflik toplumsal ve tarihsel oluşum sürecine bağlıdır (Bal, 2015, s. 105). Diğer bir ifade ile buradaki sübjektiflik aslında gerçekliği yeniden yaratan temel unsurdur. Marksizm'in bakış açısından estetik, materyalist bir varlık anlayışına dayandığı halde, sübjektivist bir gerçeklik anlayışı temelinde şekillenir (Tunall, 1976, s. 102-103). Marksist estetikte, doğada bulunan objelere, insanlara, olaylara ya da durumlara sanatçının müdahalesi şart ve gereklidir. Öte yandan saf bir gerçek değil sanatçı tarafından ideolojik temelli yaratılan bir sanattan söz edilebilir. Burada sanatçının gerçeğin kopyasını üretmesi değil, belirli bir ideolojik perspektiften eserini yansıtması esas alınır. Benzer şekilde Marksist estetiğe göre sanat eseri sınıf çıkarlarının çarpıklığını dile getiren ideolojik bir bakıştır (Moran, 2002, s. 44). Örnek olarak, sanat eserinin burjuva toplumundaki sınıfsal çatışmaları ifşa etmesi beklenebilir.

Marks ve Engels, sanatsal yöntem yerine doğrudan ahlak dersi veren, öğreticiliğe soyunan, yaşayan karakterler yerine soyut kişileştirmeler kullanan estetiğe karşıydılar (Krylov, 2009, s. 21). Engels, Margaret Harkness'in City Girl adlı eseri için yazdığı eleştiride: "Yazarın görüşleri ne denli gizli kalırsa sanat yapıtı için o denli iyi olur. Benim sözünü ettiğim gerçekçilik, yazarın kendi görüşlerine rağmen kendine bir geçit bulabilir" demektedir (Marks ve Engels, 1990, s. 71). Aynı şekilde Engels açıkça taraf tutan edebi- 
yattan hoşlanmaz, ayrıca bunu doğru da bulmaz (Belge, 1989, s. 35). Diğer bir ifade ile yapıtın mesajının kaba ve direkt şekilde okuyucunun ya da izleyicinin karşısına çıkması tercih edilmez. Engels'in edebiyat için yaptığı bu yorum diğer sanat dalları için de genelleştirilebilir. Aynı şekilde Marksist estetik için seyirci ve okuyucu açısından metni anlayıp yorumlayabileceği bir alanı olması gerektiği de söylenebilir. İzleyicilerin rolü, çoğunlukla Grundrisse'nin başındaki "üretken tüketim" yorumundan destek alan düşün insanları tarafından, kısmen sanat eserinin yapıcıları olarak ifade edilir (Bottomore, 1993, s. 204). Marksist sanat anlayışında yapıtı üreten sanatçı, izleyicinin ya da okuyucunun toplumsal ve politik temelde yorum yapabilmesini ve eyleme geçmesini amaçlamalıdır (Bal, 2015, s. 101). Sanat yoluyla toplumsal sorunları muhakeme eden izleyici daha sonra da bu sorunlara eylemsel olarak karşı çıkmalı ya da tepkisini dile getirmelidir. Aksi takdirde sanatçını işlevini tam olarak yerine getiremediği de düşünülebilir.

Sanat eserinin estetik değerlendirmesi kabaca biçim ve içerik/öz şeklindedir. Bir sanat yapıtında biçim denildiğinde sanata/forma ilişkin öğeler, içerik denildiğinde de hayata/gerçeğe ilişkin öğeler anlaşılır (Belge, 1989, s. 41). Marksist estetiğe göre, salt biçim önemli değildir, esas hedef içeriktir/özdür çünkü öz, insana ve topluma ait olandır ancak biçim, sanatı sanat yapan özelliktir (Tunall, 1998, s. 82). Moran'a göre Marksist estetik her şeyden önce yapıtın içeriğine odaklanır (2002, s. 88). Bu açıdan eserin konusu ve karakterler, burjuva sömürücü sınıfının çıkarlarına yardımcı olmamalı, alt sınıfa mensup kişilerin çıkarlarını korumalıdır (Moran, 2002, s. 88). Timuroğlu'na göre ise "Marksist estetik, biçimi içerikten ayıran biçimciliğe (formalisme), biçimle içeriği özdeşleştiren doğalcılığa (naturalisme) karşıt olarak, öz-biçim bütünlüğünü, yani öz ile öze uygun en yetkin biçim dengesini, sanatsal yaratışı önemli öğesi olarak görür" (2013, s. 463). Diğer bir ifade ile Marksist estetik toplumsal gerçeği, seyirciyi etkileyebilecek en iyi biçimde sunulmasını ister. Benzer şekilde Marksist estetik her türden sanatsal biçimciliğe geleneksel olarak karşıdır; sanat yapıtını estetik bir oyuna indirgeyen ve dikkati teknik niteliklere yönelten biçimciliği eleştirir (Eagleton, 2014, s. 35). Ancak Brecht ve Adorno sanat yapıtında modern biçimci estetiği, avangardı, biçimsel denemeleri savunur (Yaren, 2010, s. 120-121). Özetle Marksist estetik açısından biçimden daha çok içerik ve bu içeriğin de dezavantajlı grup lehinde oluşması gerekmektedir. Sanat nesnesiyle karşıla- 
şan insanların üzerinde bulunulan durumla ilgili bir farkındalık oluşması önemlidir.

Sanatın dönüştürücü bir güce sahip olduğu düşüncesi eleştirel yaklaş1mın önemli bir savı olarak öne çıkmaktadır. Marksizm özelinde sanatın gelişmesinin dünyayı dönüşüme uğratması, diğer bir ifade ile sanatın toplumun örgütleniş mücadelesinde yer alması, insanlığın sanatsal gelişmesiyle yeni bir toplumsal sistemin kurulması da amaçlanır (Çalışlar, 1990, s. 15). Bu açıdan "Komünist bir toplumda ressamlar yoktur, olsa olsa diğer şeylerin yanı sıra aynı zamanda ressam da olan insanlar vardır" (Marks ve Engels, 2013, s. 340). Marks sanatsal gelişmenin, toplumsal ilerlemenin bir nedeni ve sonucu olarak ele alınabileceğini vurgular. Sanatı ileri bir toplumda herkes yüksek bilinç düzeyine erişir. Böylece sanat hem toplumsal ilerlemeyi sağlar hem de gelişmiş bir toplumda normal olarak her bireyde az ya da çok öğrenilmiş beceri olarak bulunur. Bu bağlamda Marksizm'e göre sanatsal yaratıcilık hem evrensel insani bir gereklilik hem de bir haz alma duyumu olarak temelde desteklenmelidir (Bottomore, 1993, s. 476). Böylece toplumsal gelişme ve ilerleme devamlı olarak sağlanabilecektir.

Marksist yaklaşımda kapitalizm ve sanat ilişkisi iki açıdan değerlendirilebilir. İlki kapitalizmin sanat ve sanatın ileriye gitmesi için elverişli ortam yaratmadığıdır; kapitalist, sanata karşı ilgi duyuyorsa, özel yaşamını renklendirmek için, bir de ekonomik olarak fazla gelir elde etmek için olabilir (Fischer, 1990, s. 45). Kapitalist sistem her durumu kâr temelli olarak değerlendirmektedir. Böyle bir durumda sanatçı artık bir meta durumuna gelmiş olan yapıtıyla emeğini piyasaya süren okuyucusunu, dinleyicisini, seyircisini, alıcısını bulmak zorunluluğunda olan bir emekçidir (Doğan, 1975, s. 319). Diğer taraftan kapitalizmin, ekonomik kâr temelinde yaklaştığı sanatın yaratımı için ekonomik kaynak oluşturduğu da doğrudur. "Kapitalizm gerçekte sanata yabancı olmakla birlikte, sanatın gelişmesine zengin anlatımlı, özgün yapıtların yaratılmasına yardım da eder"' (Fischer, 1990, s. 45). Kâr amaçlı yaklaşım belli oranda sanatçıya bir hareket alanı sağlamaktadır. Aynı şekilde sanatını yerine getirmek için saraylara, soylu sınıfa dayanmak zorunluluğundan kurtulan sanatçı da özgür bir insan olur (Doğan, 1975, s. 319). Sanatın ekonomik sistemle olan ilişkisi onun niteliğini şekillendirmektedir. Bir yönüyle belli oranda bir özgürlük alanı yaratırken, diğer yönüyle onu ticari bir metaya dönüştürmektedir. Marks, kapitalist toplumda sanat ve sanatçının durumunu şöyle örnekler: 
“Kayıp Cennet'i (Paradise Lost) 5 pounda yazmış olan Milton, üretken olmayan bir emekçiydi. Buna karşılı, yayımcısına fabrikasyon iş çıkaran yazar, üretken bir emekçidir. Milton, Kayzp Cennet'i, bir ipek böceği nasıl ipek üretiyorsa öyle üretmiştir. Sonra da ürününü 5 pounda satmıştır. Oysa yanında çalş̧tığı yayımonnn yönetimi altında kitap (söz gelişi, İktisat Kılavuzu) imal eden Leipzig'li bir edebiyat işçisi, üretken bir emekçidir; çünkü ürünü daha işin başından sermayenin sultası altındadır ve ancak o sermayeyi arttırdığı oranda varlı̆̆ını kazanır" (Marks ve Engels, 1990, s. 120).

$\mathrm{Bu}$ bağlamda burjuva toplumunda her yapı, maddi meta değerine göre ölçülen "şeylere" dönüşür. "Kapitalizmde insan meta değeri olan, üstelik sonunda en değersiz metaya indirgenen nesnelerden biridir. İnsanın bu sefil durumu, bu dönüşüme paralel sanat akımlarının yapıtlarında da görülür. Empresyonist yapitlarda insan 1şık, renk ve lekeye indirgenir" (Bal, 2015, s. 99). Öte yandan genel olarak "sanat, toplum için midir?" yoksa "sanat, sanat için midir?" yıllardan gelen temel sorunsaldır; günümüz kapitalist tüketim toplumunda ise "sanatın para için mi" yapıldığı sorusu da akla yakın gelmektedir. Bu bağlamda "sanat için sanatın", "para için sanat" haline dönüştüğü de söylenmektedir (Plehanov, 1967, s. 111). Sanat dünya tarihinde görülmemiş biçimde ticari bir meta olarak milyonlarca dolar değerine alınıpsatılan, kâr edilen, üzerine manipülasyonlar yapılan bir alan haline getirilmiştir. Öte yandan Ortodoks Marksist sanat anlayışı, burjuva sınıfının desteklediği ve "sanat, sanat içindir" ifadesinde özetlenen mimesis kuramının dışına çıkamayan, gerçekçi sanata ya da insan ve toplumla ilişkisi neredeyse kopmuş soyut sanata karşı çıar (Bal, 2015, s. 101). Bu iki sanat yaklaşımı içinde dengeyi bulmanın önemi vurgulanmaktadır. Sınıfsal çatışmalarının gerçekliğini ortaya koyabilecek, aynı zamanda anlamsal bağların kopmadığı bir biçimselliği barındıracak sanat üretimi Marksist yaklaşım tarafından olumlanmaktadır.

Marksizm açısından ideoloji, "sınıflı bir toplumda insanların yaşadığı roller, değerler, onları toplumsal işlevlerine bağlayan ve böylelikle bir bütün olarak toplumunun doğru bilgisine ulaşmalarına engel olan düşünce ve imgeler anlamina gelir" (Eagleton, 2014, s. 30-31). Sanatın ideolojiden bağımsız olması da pek düşünülemez. Kapitalist sistemde sanatın konumunu eleştiren Behrens günümüz sanatlarının en önemli işlevlerinden birinin kapitalist burjuva ideolojisini estetik olarak meşrulaştırmak olduğunu belirtir (2011, s. 196). Bu bağlamda sanat, kapitalist ideolojinin yanlışlarını örten 
bir araca dönüşür. Marks da kapitalist toplumda insan bilincinin çarpıtılmış ve bozulmuş olduğunu ve bundan ötürü insanın dünyayı yanlış bir açıdan gördüğ̈nü vurgular (Hauser, 1984, s. 385).

"İşte tam bu noktada sanat, üretim ilişkilerini kapitalist sistem çıarnna yeniden düzenleyen ve gönüllü itaati sağlayan ideolojik bir aygıt olarak tanımlanabileceği gibi, insan üreten bir varlk olarak, aklını ve zihnini, sistem adına organize edilmiş düşünce biçimlerini sorgulama amactyla kullanan bir birey haline getirebilen estetik bir yaratı olarak da düşünülebilir" (Kılınç, 2008, s. 221).

O zaman Marksist yaklaşıma göre sanat "yanlış bilinci" açığa çıkarma işlevine sahip olmalıdır. Yoksa sanatın meta değerinden başka bir işlevselliği kalmayacaktır. Bu da eleştirel yaklaşımdan kabul edilemez bir durumdur.

\section{Theodor Adorno ve Walter Benjamin Perspektifinden Sanat ve Estetik Kavramı}

Marksist estetiğe modern dönemde en önemli katkıları yapan isimlerden biri Adorno'dur. Adorno'ya göre burjuva sisteminde toplumsal gerçeklik, hatalı ve çarpıtılmış bir durumdadır. Bu nedenle, toplumsal gerçeklik sanat yapıtı için doğru bir örnek olmaktan uzaktır (Tunalı, 1998, s. 127). Diğer bir ifade ile sanatın çarpıtılmış olan toplumsal gerçeği sunma, ortaya koyma ya da yansıtma gibi bir işlevi olamaz. Adorno'ya göre sanat, toplumsal gerçekliği yansıtmayacak ancak toplumun yanlışlıktan ve çarpıklıktan kurtulması için kılavuzluk edecektir (Bozkurt, 1995, s. 246). Bu açıdan sanatın ve sanatçının ortaya koyduğu gerçeklik toplumsal yapının ilerlemesine ve gelişmesine temel oluşturur. Adorno'nun önemli temsilcisi olduğu Frankfurt Okulu düşünürleri ise sinema temelinde kitle iletişim araçlarının gerçekliği ideolojik olarak çarpıttığını belirtirler. Adorno'nun yaklaşımına göre kültür endüstrisi ürünleri metalaşmış sanat yapıtları değildir; başlangıcından itibaren kapitalist sistemde kâr amaciyla üretilmiş uydurma ürünlerdir (Jay, 2001, s.167). Bu bağlamda kültür endüstrisi eğlenme işlevi görür, burada kültür salt eğlence demek, sanat ise insanları oyalayan yapı demektir (Behrens, 2011, s.73). Diğer bir ifade ile sanatın estetik değeri burjuva ideolojisi tarafından yadsınır. Kültür endüstrisi kavramı, sanatı bir meta olarak, sanat izleyicisini bir tüketici olarak ve sanat sergisini ise bir pazar yeri olarak betimler (Beech, 2015, s.226). Aynı şekilde pazar ekonomisinin kurallarına 
bağlı kılınan sanat eserleri alınıp-satılan dekoratif unsurları ön planda olan basit mallara dönüştürülür. Adorno'ya göre kapitalist temelli kültür endüstrisinde sanat yapıtının kitlesel üretimi/tüketimi söz konusudur (2000, s. 53). Sanatın hem yapıtın oluşturulma aşamasında hem de seyirci tarafından alımlanması aşamasında biricik ve kişisel olan yanı burjuva toplumunda geçerli değildir. Öte yandan Adorno kültür endüstrisi içinde yetişen kimselerin sanat ve estetik hakkında yeterli bilgiye sahip olamayacağını söyler (2002, s. 16). Kapitalist sistemde sanat ve estetik hakkında da bilgi sahibi olmak imkansızlaşır. Ona göre özellikle sinema ideolojik olarak seyirciyi manipüle etmektedir. Film, gündelik hayatın yaşam dünyasını yeniden oluşturmayı amaçladığından, gerçek hayatı izledikleri filmin devamı zanneden bir kitle oluşturur (Horkheimer \& Adorno, 2014, s. 169). Bu kitleden estetik bir değer beklemek mümkün değildir. Ayrıca kültür endüstrisinin sanat (!) yapitları sığ ve standarttır (Adorno, 2002, s. 246). İnsanların kapitalist toplumda ideoloji temelinde kültür endüstrisinden nasıl etkilendiğini örnekleyen Kellner'e göre 1980'lerdeki Thatcher ve Reagan'ın toplumları üzerinde kurdukları hegemonyayı açıklamak için medyada, okullarda ve kültürün geneline nasıl egemen olduklarının analiz edilmesi gerekmektedir (2016, s.137). Bu bağlamda, kitle iletişim araçları kadar, kültür endüstrisinin bir ürünü olan sanatta ideolojik olarak toplumları biçimlendirmede önemli bir işleve sahiptir.

Adorno, genellikle Ortodoks Marksist bir estetik görüş olan yansıtmac1lığa, mimetizme karşıdır (Soykan, 2003, s. 57). Doğanın taklidine dayalı bir sanat anlayışını işaret eden mimesis Antik Yunan düşünüşüne dayanmaktadır. Adorno, sanat eserinin yaşamı yansıtan bir ayna olduğuna dair düşünceyi reddeder. Sanat olabilecek alternatiflerin yaşandığ bir alandır (Dellaloğlu, 2003, s. 60). Adorno özelinde sanat, hayatı "sanatsal gerçeklik" temelinde anlamlandırmalı ve "toplumsal gerçeklik" temelinde alternatif bir alan işlevi görmelidir (Zeytinoğlu, 2003, s.247). Bu alternatif alan kitleleri doğru bilgilendirmeye de yaramaktadır. Adorno'ya göre sanat, ne toplumu onaylamalı ne de reddetmelidir ancak eleştirmelidir (Soykan, 2003, s.58). Bu eleştirme sayesinde yeni bir kültür hareketi mümkün olabilecektir. Bu bağlamda sanat, burjuva toplumsal gerçekliğine karşı bir protesto temelinde karşı kültür meydana getirebilir (Bozkurt, 1995, s.246-247). Ortodoks Marksist düşünürlerin modern sanata getirdikleri apolitiklik eleştirisini Adorno kesinlikle reddeder (Dellaloğlu, 2003, s.60). Dada akımı gibi aşırı biçimci 
sanat estetiğini özünde modern kapitalist ideolojiyi eleştirdiği için destekler. Eleştiriyi sanatın en önemli niteliklerinden biri olarak öne çıkartır.

Marks'ın estetik anlayışına katkı sunan düşünürlerden biri de Walter Benjamin'dir. Benjamin teknik çoğaltımın öne geçtiği modern dönemde artık sanatın biricikliğinin ortadan kalktığını belirtir. "Örneğin bir fotoğrafın negatifinden çok sayıda baskı yapılabilmektedir; hangisinin özgün baskı olduğu sorusu bir anlam taşımamaktadır." (2002, s. 58-59). Benjamin açısından herhangi bir sanat eserinin fotoğraf ve film gibi teknik aletler ile mükemmele yakın yeniden üretimi sanatın geleneksel anlamı ile büyüsünü, modern anlatım ile aurasını ortadan kaldırır. "Sanat yapıtının biriciklik ve hakikiliğinin kaybı, aristokratik bir haz nesnesi olmaktan çıkması anlamıyla, aynı zamanda bir demokratikleşme olasılı̆̆ı anlamına gelir" (Mollaer, 2007, s. 246). Ortaçağ dönemindeki gibi sadece kralların ya da zengin aristokrat sınıfın değil; sanata bütün halkın ulaşabilmesinin önü açıldığı için, sanatın demokratikleştiğini söylemektedir. Diğer yandan Benjamin'e göre dünyevileştirilmiş ve metalaştırılmış bir dünyada nesnelerin halesi, sembolik değerlerini yitirir (Özbek, 2000a, s. 89). Benjamin halenin ne olduğunu şöyle açıklamaktadir:

"Zamanın ve mekanın oluşturduğu tuhaf bir ağ: ne kadar avcunuzun içindeymiş gibi görünürse görünsün, belli bir mesafede duran bir şeyin tek bir kezlik görünümü. Bir yaz gününde, anın ya da saatin de görünümün parçası olmaya başladı̆̆ı noktaya kadar bir dă̆ silsilesinin ufukta oluşturduğu çizgiyi ya da gölgesini kendi üstüne düşüren bir dal parçasın seyrederek uzanmak işte o dağların, o dal parçasının halesini hissetmek denen şey budur" (Benjamin, 2013, s. 24-25).

$\mathrm{Bu}$ açıdan hale kişinin ruhsal dünyasında tanımlamaya çalıştığı hayali imgeler toplamıdır denebilir. Öte yandan Benjamin sanatın, manevi halesinin ortadan kalkmasından sonra artık politik alanın hizmetine girdiğini belirtir (Özbek, 2000b, s. 126). Örnek olarak Brecht'in epik tiyatro anlayışını ve Chaplin' in filmlerini veren Benjamin, sanatı yeni bir siyasal devrim aracı olarak görmektedir (Witte, 2002, s. 132). Bu yapitlarla toplumun ideolojik ve politik olarak bilinçlendiğini düşünmektedir. Ayrıca sanatın kitlelerin özgürleşmesinde potansiyel bir araç olduğunu belirtir (Yaren, 2010, s. 116). Aynı şekilde kapitalist toplumda sanatın toplumu düşünsel anlamda ileriye taşıma özelliği bulunmalıdır. 
"Benjamin'e göre sanat yapıtının törensel işlevinin kaynağı olan kutsallığını, kült değerini terk edip, teknik yeniden çoğaltımla daha çok insana ulaşması müziğin artık sadece kiliselerde ayinler strasında değil, evlerde de dinlenilebilir olmast- bir tür demokratikleşme hareketidir. Oysa Adorno'ya göre sanat yapittnın şimdi ve buradalığın kaybetmesi, örneğin müziğin evlerde dinlenebilir olmasl, herkesin aynı şeyi tüketmesine neden olan kitleselleşmenin bir sonucudur" (Artan, 2007, s. 90).

Bu bağlamda Benjamin ve Adorno arasında zıtlık ortaya çıkmaktadır. Benjamin sinema, fotoğraf, müzik gibi kitleselleşebilen sanatların demokratik devrimci bir hareket olduğunu düşünmekteyken, Adorno ise kapitalist kültür endüstrisi temelinde bu tip sanatların kitleselleşmesinin insanları ideolojik olarak yanlış yönlendirdiğini ifade etmektedir. İki farklı eleştirel yaklaşımında kendi için oldukça tutarlıdır.

\section{Lee Jeffries'in Portre Fotoğraflarinin Eleştirel Perspektiften Biçimsel Analiz İle Çözümlenmesi}

İngiliz asıllı olan Lee Jeffries genellikle portre çalışmalarıyla tanınan bir fotoğrafçıdır. Sanatçı, çalışmalarında evsizleri konu edinmesinin nedeni olarak yaşadığı bir anıyı anlatmaktadır. Jeffries Londra'da bir maraton koşusunun fotoğrafını çekmeye gider. Yarıştan bir gün önce sokakta yatan genç evsiz bir kızın fotoğrafını 200mm tele objektif ile çekmeye çalışır; kız fotoğrafının çekildiğini görür ve Jeffries'e bağırır bunun üzerine Jeffries utanır, bir an duraksar ve kızla konuşmaya başlar (Julie, 2015). Bu olay onun hayata ve fotoğrafçılığa bakışını tamamen değiştirir. Jeffries, fotoğraf çekmeden önce evsizlerin kaldıkları yerlerde haftalarca onlarla aynı koşullar altında yaşar, kendi fotoğraf çekme sürecini dışarıdan değil, "içten dışa" doğru fotoğraflama şeklinde adlandırır (Julie, 2015). Jefries "içten dışa" fotoğraf yaklaşımıyla konu olarak seçtiği kişilerin duygusal durumları ve yaşam koşulları hakkında da derinlemesine bilgi sahibi olmaktadır. Onları daha iyi anlayabilmek adına aynı koşulları onlarla birlikte paylaşmaktadır. Diğer yandan Marksist estetiğe göre kolektif koordinasyon, işbirliği ve emek, sanat eserinin kendisine ve üretimine dâhil edilmelidir (Pickford, 2017, s. 38). $\mathrm{Bu}$ açıdan Jeffries'in fotoğraf üretim sürecinde evsiz insanlardan destek aldığını ve onların görüşleri yardımıyla sanatını oluşturduğunu da söylemek mümkündür. 
Jeffries fotoğraflarını çekmeden önce seçtiği kişilerle konuşmakta, onlar ile vakit geçirip nelerden hoşlandıklarını, nelere önem verdiklerini ve hayat hikâyelerini dinlemektedir. Bu bağlamda fotoğrafçı eserini yaratırken sadece anlık görüntülerin uzaktan yakalanmasına dayalı bir doğaçlama biçim tercih etmemektedir. Önceden belirli düşüncesel tasarım ile estetik ve ideolojik kaygiların temelinde fotoğraf çekmektedir. Bunu yaparken de kişilerin bulundukları konum itibariyle biçimsel olarak güzel, çekici, ilginç olmalarına dikkat etmemektedir. Marksist estetikte sanatçı gerçekleri yansıtacaksa "çirkin", "iğrenç" ve "ayıp" olarak kabul edilen olgular da sanata konu edilebilmelidir (Ötgün, 2008, s. 172). Aynı şekilde Marksist estetik, burjuva ideolojisinin merkezi kategorisi olan "güzel" fikrini sanat kategorisinde kesin bir şekilde reddeder (Marcuse, 1978, s. 62). Diğer bir ifade ile insanların zihinsel dünyalarında "iyi", "olumlu" ve "güzel" olarak tanımlamadığ 1 evsizleri yeni, yaratıcı ve duyarlılıkla sunmaktadır. Bu bağlamda Jeffries'in insanların düşünce evrenlerinde alt sınıf olarak nitelenenlere karşı yeni bir bakış açısı geliştirdiği ve fotoğrafı farklı toplumsal sınıfların birbirilerini doğru ve gerçekçi tanımaları için bir araç olarak kullandığını ifade etmek mümkündür.

Jeffries' in fotoğraf ekipmanları incelendiğinde ise sıradan sayılabilecek donanımlarla çalıştığı görülmektedir. Herkesin sahip olabileceği dijital bir fotoğraf makinesi, geniş açılı bir lens ve el reflektörü ile fotoğraflarını çektiği anlaşılmaktadır. Uzunca bir süre portre fotoğraflarını Canon 5D mark 1 model bir gövde ve $24 \mathrm{~mm} / \mathrm{f} 1.4$ lens ile çeker. Tanınmaya başladıktan sonra sanat galericilerinin çok daha büyük boyutlu fotoğraflar istemesi nedeniyle gövde olarak Nikon D850 model fotoğraf makinesi kullanmaya başlar (Child Photo Competition, 2018). Bu tarz basit ekipman tercihi onun daha mobilize ve rahat çalışmasını sağlamaktadır. $24 \mathrm{~mm}$ geniş açılı lens, özellikle portre fotoğraflarda geniş bir yüzey imkanı tanımakta ve dokuların detaylarını ortaya çıkarmak adına önemli bir işlev görmektedir. Bu da Jeffries'in portre fotoğraflarında daha "dramatik" ve "vurucu" kadrajların ortaya çıkmasını kolaylaştırmaktadır.

Jeffries' in çoğu zaman siyah-beyaz fotoğraf biçimini tercih ettiği görülür. Siyah-beyaz tercihi, dikkati konuya odaklama noktasında avantaj sağlamaktadır. Çarpıcı renklerden arındırılmış bir fotoğrafta, konunun ön plana çıkması daha kolaydır. Ayrıca siyah-beyaz fotoğraf tercihi hayatın "kıyısında" yaşayan, renkli/parlak bir hayatı olmayan insanların içinde bulunduğu at- 
mosferi yansıtmak adına daha uygundur. Öte yandan sanatçının genelde kullandığı koyu arka fon, modern şehir hayatının evsizler bağlamında belirsizliğini ve tekinsizliğini ortaya koymaktadır. Fonun koyu olması kişilerin yüz hatlarının kontrast aracılığıyla daha fazla ortaya çıkmasını sağlamaktadır. Kentin arka sokaklarında ve silik, görünmeyen/görülmek istemeyen insanları, geniş açılı lensle kadrajın tamamına oturtarak, görünür olmalarına imkân tanır. İzleyici fotoğraflarda onlarla yüzleşmek durumunda kalmaktadır. Böylece sanatçının fotoğrafları, aynı zamanda demokratik bir işlev kazanmaktadır. Jeffries' in bu yaklaşımı Marksist estetiğin beklediği, aktif ve yorum yapabilen izleyiciler oluşturmaya yönelik tavrına da uygundur. Jeffries, "Tamamen görsel bir referansla izleyiciden yaratıcı ve akıllı bir tepki yaratmaya çalışıyorum. Bunu arka plandaki dikkat dağıtııı şeyler olmadan gerçekleştirmeye çalışıyorum" cümlesiyle neden fonda başka dikkat dağıtıcı ögeler olmadığını da açıklar (Julie, 2015). Diğer bir ifade ile seyircinin, ana öğe olan evsizlerin portreleri dışında başka bir şeye odaklanmalarını istememektedir (Bknz. Fotoğraf 1). Jeffries, kurduğu portre kompozisyonlarında konularını genellikle merkezleyerek denge kurar. Fotoğraflar genellikle göz hizasından çekilerek izleyicisiyle dengeli bir iletişim kurulur. Sanatçının portre çekimlerinde baş boşluğu bırakmadığı görülmektedir. Böylelikle izleyicinin tüm dikkati gözlere ve yüzün merkezine doğru odaklanmayı sağlamaktadır. Ciltteki dokulardaki keskinlik etkisi, fotoğrafçının yüksek enstantene değerleri kulladığını gösterirken, alan derinliğinin kısa mesafede sığlaşması açık diyafram değerlerini işaret etmektedir. Ayrıca optik olarak alan derinliğinin sığlaşması yine izleyici dikkatini portrelerin merkezine doğru çekmektedir. Fotoğraflarda simetrik dengeye de dikkat edildiği görülmektedir (Bkzn. Fotoğraf 1-2-3). 


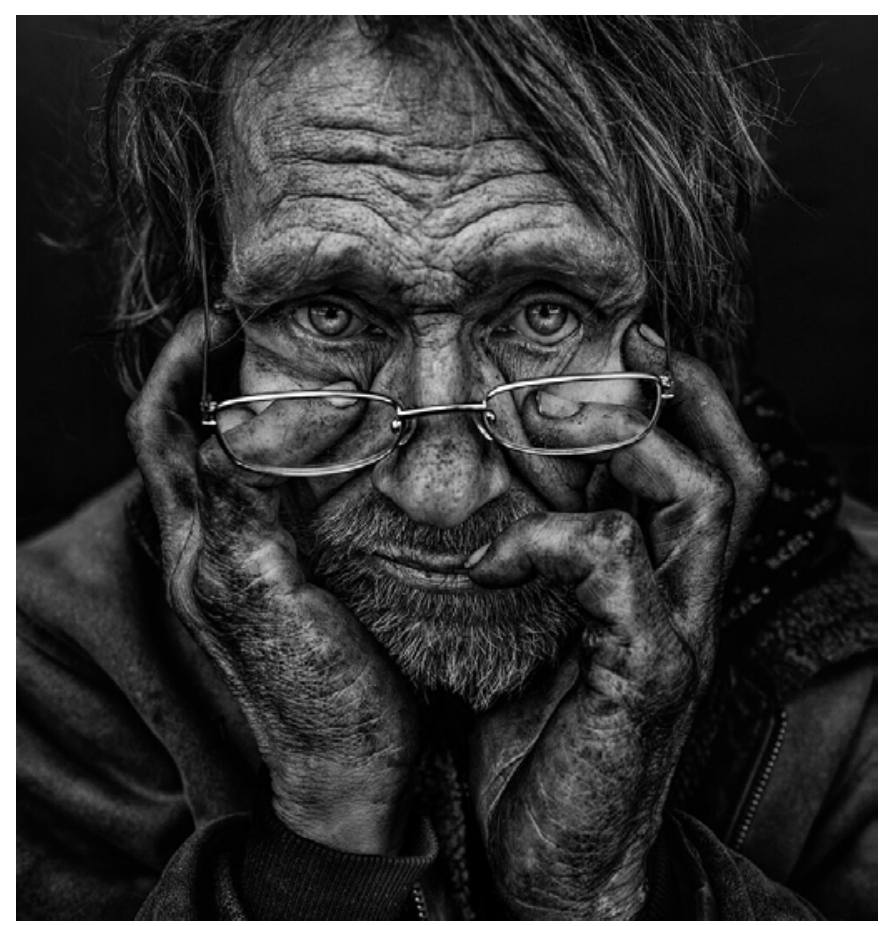

Fotoğraf 1. Thomas, Sanatçı: Lee Jeffries, Dijital Portre Çalışması Kaynak: (Jeffries, 2019https://lee-jeffries.co.uk/)

Marks her şeyden önce sanatı ve estetiği, insanın yaratıcı gücünün bir özelliği olarak görmektedir (Rader, 1967, s. 247). Marksist estetikte sanat yapıtı direkt olarak gerçekliğin kopyası değildir, insanın hayal dünyasının gerçeklikten elde ettiklerini düzenlemesi, onları yeniden biçimlendirip kendine özgü hale getirmesidir (Tunalı, 1998, s. 80). Bu bağlamda Jeffries'in fotoğrafları incelendiğinde toplumsal yaşamdaki gerçeğin birebir kopyası olmadığı ve fotoğraflara stilizasyon aracılığıyla yeniden düzenleme yaptığı ortaya çıkmaktadır. Sanatçı dijital olarak ürettiği fotoğraflarında müdahalelerle oldukça keskin ve kontrastlı bir doku yaratmaktadır. Böylece Jeffries kapitalist toplumsal yaşamda modern ve kentli insanın görmezden geldiği "evsizleri" yüksek kontrastlı ve keskin görüntülerle daha çarpıcı/dikkat çekici hale getirmektedir. Jeffries'in önceden tasarlanmış ve belirli noktaları özellikle vurgulayan biçimci/stilize bir üslup kullandığı görülmektedir. Bu bağlamda öz ve biçim arasında Marksist estetik açısından bir denge oluşturduğu söylenebilir. Diğer bir ifade ile Jeffries dijital olarak fotoğrafın üze- 
rinde yaptı̆ yüzlerinde ve yüzlerindeki keskin izlerde yoğunlaştırmaktadır.

Marksist estetik açısından Jeffries'in fotoğraflarında diğer dikkat çekici anlayış onun egemen sınıfın zıddında yer alan, geçinecek parası dahi olmayan ve sokaklarda yatmak zorunda kalan kişileri ana konu olarak seçerek, onları özne konumuna yükseltmesidir. Diğer bir ifade ile fotoğrafçı toplumda en alt sinfta yer alan insanları ve onların problemlerini sanat yoluyla dışa vurmaktadır. Bu bağlamda Jeffries'in egemen ideolojiye karşı bir duruş sergilediği söylenebilir. Sinemada, televizyonlarda ve sosyal medyada özellikle ana akım medya içerikleri, kültür endüstrisi bağlamında genellikle geniş/ferah mekânlarda ikamet eden, sürekli tüketen, toplumda saygin bir mesleği olan Batılı insanları öncelemektedir. Ancak fotoğrafçı, kültür endüstrisinin zıttı yönünde bir temsiliyet sunmaktadır. Bu bağlamda Jeffries'in, Benjamin'in vurguladığı sanatın gündelik hayattaki eleştirel ve politik konuları topluma iletme rolüne uygun davrandığı görülmektedir.

Jeffries kapitalist toplumun sanat-meta ilişkisini de bir nevi yapı bozumuna uğratmaktadır. Jeffries çoğu zaman toplumun görmezden geldiği, yan yana gelmekten çekindiği evsiz insanların portrelerini ünlü kişilerin satın alıp evlerinde sergilemelerini sağlamaktadır. Ünlü kişilerden örnek olarak instagramda 4.6 milyon takipçisi bulunan Amerikalı şarkıcı ve söz yazarı Nicole Scherzinger ve instagramda 17.1 milyon takipçisi olan Amerikalı oyuncu Channing Tatum verilebilir. Ayrıca bu ünlü kişiler sosyal medya üzerinden, evsizlerin fotoğrafları ile kendilerinin paylaşımını yapmaktadır. Bu bağlamda fotoğrafçı, toplumsal alanda fazla değer verilmeyen evsizlere, maddi ve manevi olarak katkılar sunmaktadır. Onlara bir saygınlık kazandırmaktadır. Aynı zamanda Instagram, Facebook gibi kültür endüstrisinin modern toplumdaki en ileri medyaları aracılığıyla dönemin egemen ideolojisine eleştiri getirir. Adorno modern toplumlarda esas mistifiye edici gücün artık ideolojiler değil, teknoloji olduğunu söylemektedir (Jay, 2001, s. 170). Jeffries ise teknoloji ile Benjamin ifadesi ile "hale", simgesel anlam yaratarak insanın bilinçlenmesi anlamında kültür endüstrisini bir anlamda tersi işlevle kullanmaktadır.

Jeffries özellikle evsizlerin portre fotoğraflarında gözleri ön plana çıkarmaktadır. Lee, fotoğrafçılığındaki dar alan derinliğinden nasıl yararlandığ1nı açılarken, odak noktasının her zaman öznenin gözleri olduğunu belirterek; bir kişinin karakterini, duygularını ve gerçek hikâyesini aktaran gözleri 
olduğunu söyler (Greatermancunians, 2020). Bu bağlamda kapitalist sistem içinde sanatçı evsiz insanlar ile burjuva toplumundaki kişileri göz göze getirme durumunu oluşturmaktadır denebilir. Herkesin sokakta gözünü kaçırdığı evsizler, kendilerini daha üst sınıfta konumlandıran insanların, fotoğraf bağlamında gözünün içine bakmaktadır (Bknz. Fotoğraf 2). Diğer yandan sosyal medya paylaşımlarında fotoğraflarını çektiği kişilerin hayatları hakkında kısa bilgiler vererek onlara yeniden bir kimlik kazandırmaya çalıştığı da söylenebilir.

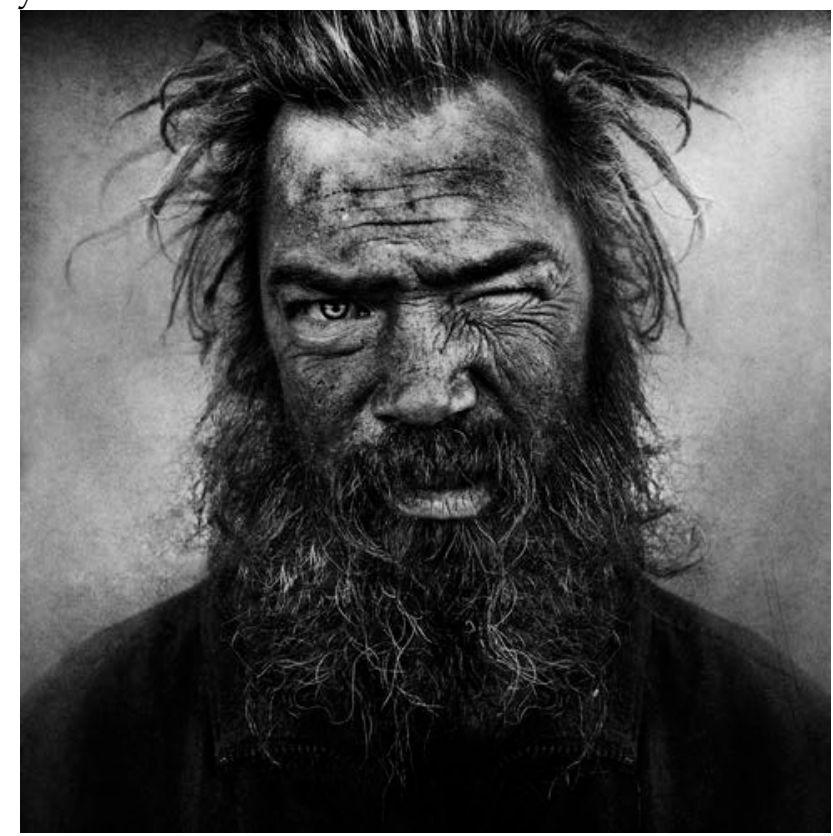

Fotoğraf 2. La III, Sanatçı: Lee Jeffries, Dijital Portre Çalışması Kaynak: (Jeffries, 2019, https://lee-jeffries.co.uk/)

Jeffries, Marksist terminolojiyle yaklaşıldığında bir tür yabancılaşma fotoğrafçılığı da yapmaktadır. Bu fotoğraflar insanın, insana yabancılaşmasını deşifre eden fotoğraflar niteliğindedir. Sanatçı, sokaktaki yaşamda zor durumda kalan birinin, kapitalist sistemde sanat yoluyla öne çıkabileceğini vurgulamaktadır. Diğer toplumsal sınıfların onların farkına varmasını sağlar. Engels, bir sanat eserinde amacın açık seçik belirtilmesinin, yapıtı zayıflattığını söyler; amaç, açıkça belirtilmemeli, durumdan ve eylemden anlaşılmalıdır (Timuroğlu, 2013, s. 137). Bu açıdan Jeffries'in fotoğrafları incelendiğinde evsiz insanları yattıkları yerlerde, harap barakalarda ya da bir 
kişiden yardım isterken betimlemez. Fotoğraf sanatçısı evsizleri bulunduğu ortamdan yalıtır. Aynı modern dünyanın evsizleri görmezden gelmesi gibi Jeffries de modern şehir hayatının kadrajına girmesine izin vermez. Onların duygu durumların portreler aracıllğıyla izleyenlere yansıtır. Jeffries amac1nı "bir duygu yakalamak istiyorum ve bu kadar yakın olmak bunu yapmama izin veriyor" şeklinde açıklar (Lomography, 2019). Bu bağlamda Jeffries' in toplumsal yaşamdaki insanlar ile evsizleri fotoğraf sanatı temelinde yakınlaştırmak istediği de söylenebilir. Bu yakınlaşma hem maddi hem de ruhani olarak amaçlanmaktadır (Bknz. Fotoğraf 3).

Marksist estetik temelinde fotoğrafçı doğal objeye kendinden, kendi ruhundan bir şeyler katar. Sanatta sübjektiviteyi, sanatçının duygusallığını, onun hayal gücünü de hesaba katmak zorunluluğunu duyar (Tunalı, 1993, s. 68-69). Diğer bir ifade ile Marksist estetikte sanat, "imgeler" aracilığıyla gerçekliğin yeniden üretilmesidir (Ziss, 1984, s. 71). İmge ise gerçekliğin sanatsal çağrışımıdır; sanatçının bilincinde oluşan nesnel dünyanın düşünsel bir tablosudur (Ziss, 1984, s. 73). Bu bağlamda yaratıcı sanatçı Marksist estetik için temel unsurdur. Adorno'ya göre de sanatçının fantezisi, olmayan bir şeyden/hiçten yaratım (creatio ex nihilo/yoktan var etmek) değildir (Kula, 2013, s. 304). Sanatsal ve estetik bilinç her zaman gerçek maddi nesnelere, uzay ve zamanda var olan nesnelere yöneliktir ve nedensel bağlantılara tabidir (Swiderski, 1979, s. 132). Jeffries "1şı̆̆1 ve gölgeyi neredeyse manevi bir şekilde kullanmaya çalışıyorum muhtemelen kasıtlı olmaktan daha içgüdüsel olarak fotoğraflama sürecin başlangicından itibaren, evsiz insanlarla ruhani bir yolculuğa giriyorum" demektedir (Yellow Korner, 2017). Bu açıdan Jeffries'in fotoğrafları incelendiğinde imgeler üzerinden evsizler temelinde birçok çağrışımsal anlam oluşturmaya özen gösterdiği ortaya çıkmaktadır. Onun evsizler üzerinden yarattı̆̆ toplumda temel olan biteni yani sınıfsal çatışmaları oldukça güçlü bir görsellikle ortaya koymaktadır. 


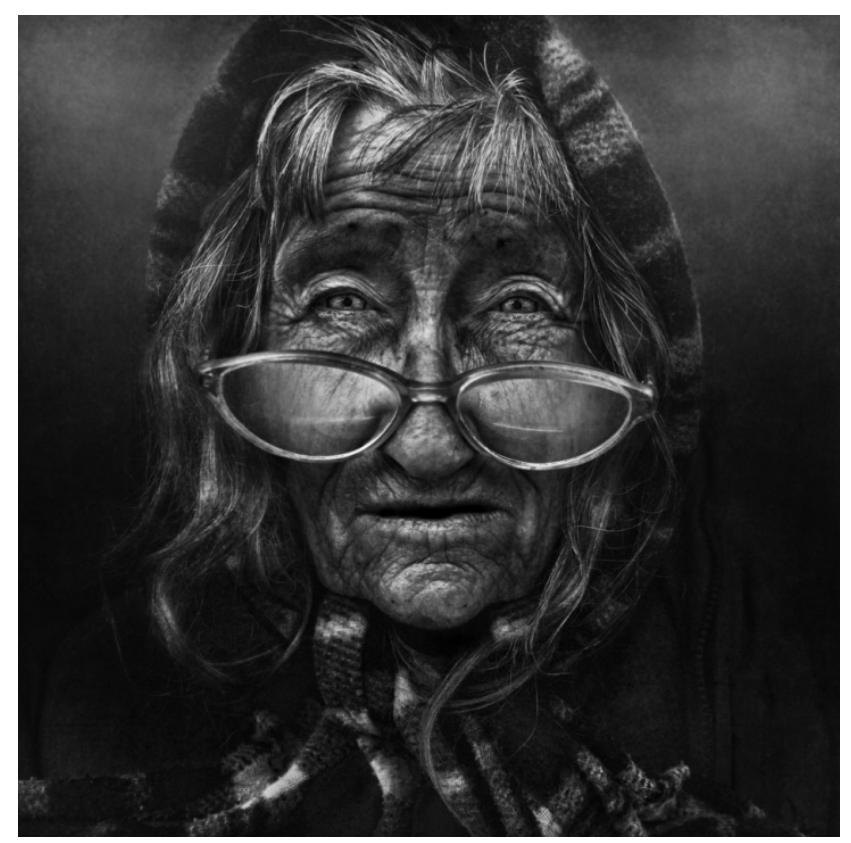

Fotoğraf 3. The Cat Lady, Sanatçı: Lee Jeffries, Dijital Portre Çalışması, Kaynak: (Jeffries, 2019, https://lee-jeffries.co.uk/)

Jeffries teknolojik imkânların kullanımına da açıktır. Bu bağlamda toplumsal kitleye ulaşmak için alternatif yollar aradığı ve bulduğu söylenebilir. "Sosyal medya, görüntülerimin ilk fark edildiği yer ve ben her gün bu ağı daha da geliştirmeye çalışıorum" diyerek alternatif kanalların önemini vurgular (Julie, 2015). Özellikle Instagram onun fotoğraflarını kitlelere ulaştırabilmesi açısından önemli bir araçtır. Bu durumu "Fotoğraf açısından bence en büyük yer Instagram. İşimi takip edenler muazzam rakamlarla beni onurlandırıyorlar" (Child Photo Competition, 2018) şeklinde vurgular. Jeffries sosyal medya hesaplarında sürekli fotoğraflarını paylaşarak insanların evsiz kimseler üzerine düşünmesi, bilinçlenmesi ve harekete geçmesine de yardımcı olur. Jeffries' in kişisel Instagram hesabında 410 bin takipçi bulunmakta ve Facebook hesabında 153 bin kişi onu takip etmektedir.

Jeffries temelde sanatsal obje olarak ele aldığı ve fotoğraf ile bir sanat eserine dönüştürdüğü olgu evsizliktir. Bu bağlamda modern Batılı hayali imgeleminin dışında, fakirlik içinde sokaklarda yaşamak ve diğer insanlara muhtaç olarak hayatlarını sürdürmek zorunda olanları bu durumu göstermeden çerçeveler. Jeffries alt sınıf da yer alan insanların kapitalist dünyadaki so- 
runlarını farklı bir estetik bakış ile yansıtmak amacındadır. Bunu yaparken özellikle yeni medyanın gücünü kullanarak sanat yoluyla toplumsal gerçekliğe insanların ulaşmasını kolaylaştırır. Jefrries "görüntülerim aracılığıyla izleyiciyle manevi ve insani bir seviyede yankı uyandırmayı amaçlıyorum ve ben de onlara kendi metafizik hikâyelerimi anlatıyorum" demektedir (Julie, 2015). Bu bağlamda Jeffries'in fotoğraflarında yarattığı en belirgin unsur Benjamin'in tabiri ile auradır. Jeffries'in fotoğrafları ve aura kavramı bir çelişki oluşturur. Jeffries aslında gerçek hayatta yaşayan insanların aurasını fotoğraf ile yaratarak politikleştirir. Fotoğrafçı sanatın hem estetik hem politik yanını gösterir. Diğer bir ifade ile normal yaşamda kimsenin bilerek ve isteyerek görmeye gitmeyeceği insanlar, auraları sayesinde üst sınıf olarak değerlendirilebilecek binlerce insanın evinde yer bulmaktadır. Heinich, aura kavramının toplumla kurulmuş vasfını ortaya çıkarmak gerektiğini belirtir (2013, s. 31). Bu bağlamda Jeffries fotoğraftaki auranın toplumsal yaşamda çoğalmasını sağlar; ne kadar fazla kişiyle fotoğraf temas ederse aurası o kadar artar. Diğer yandan Benjamin "kitle sanatının ve teknolojinin devrimci amaçlarla kullanılması yoluyla auranın yitiminin yarattığı tinsel boşluğun doldurulabileceğini düşünmüştür" (Demiralp, 2007, s. 76). Seyirci sanatın toplumsal amaçlarla kullanılması sonucu yeni bir auraya kavuşur. Jeffries kendi sanatına dair birçok takipçi yaratmış bir kişiliktir. Binlerce insan onun fotoğraflarını sosyal medyadan takip eder. Benjamin fotoğrafın kitle kontrolü kadar kitlesel reaksiyon aracı olarak kullanımını da belirtmektedir (Yacavone, 2015, s. 42). Bu açıdan Jeffries'in fotoğrafları, evsiz insanların özelinde dezavantajlı grupların lehine bilinç oluşturan bir yapıya sahiptir.

\section{Sonuç}

İnsan ilkel dönemlerinden itibaren sanat, üretim ve haz etkinliği olarak toplumsal alanda var olmuştur. Marksist estetiğe göre sanat, insanın doğal hayatı değiştiren ve dönüştüren bilinçli emeğinin bir ürünüdür. Diğer bir ifade ile insan, yaratıcı eylemleriyle kendi kültürünü ve sanatını meydana getirmektedir. Bu bağlamda, insanın dünyayı dönüştürme gücü, sanatın yasalarını da süreç içerisinde belirlemesini sağlar. Tarihsel ve toplumsal ilerleme ile birlikte sanatın ve sanatçının anlamı da değişmektedir. 
Kapitalist üretim ve tüketim ilişkilerinin yoğun olduğu modern dönemde sanat, toplumsal yaşamı biçimlendiren egemen ideoloji tarafından "yanlış" yönlendirilebilmektedir. Sanat, üstsınıfa ait/burjuva değerlerini meşrulaştırma işlevinden sıyrılmalıdır. Marksist estetiğe göre sanatçı bu aşamada meydana getirdiği eserler ile alt sınıfı bilinçlendirme görevine haiz olmalıdır. Lee Jeffries, fotoğrafı yaratıı biçimsellik ve toplumsal gerçekçi bir içerik ile yansıtarak kapitalist sistemde kitleleri bilinçlendirme görevini gerçekleştirir. Fotoğrafçının izleyici temelinde, özellikle evsizlik kavramı ve evsizler üzerine düşünme ve eyleme geçirme işlevini başardığı söylenebilir. Bunu yaparken de bilinçli ya da bilinçsiz olarak Marksist estetiğin bir takım normlarına uygun hareket ettiği de ortaya çıkmaktadır.

Fotoğrafçı ilkel kabilelerde büyücünün görevini değişik biçimlerde de olsa modern dünyada devam ettirme eğilimi içindedir. Büyüsü bozulmuş tüketim odaklı modern dünyayı fotoğraf sanatının estetik unsurları ile yeniden büyülemek istemektedir. Bu durum Benjamin'in fotoğrafın halesi dediği duygu durumuna da denk düşmektedir. Diğer yandan Adornónın kitle iletişim araçlarının insanları pasifleştirdiği yargısının tersine Jeffries, fotoğrafın insanları etkileme, farkındalık yaratma ve ortak duygu durumlarını paylaşma işlevini kullanmaktadır. Aynı şekilde fotoğrafçının kapitalist sistemin argümanları ile burjuva toplumsal yapısını eleştirdiği de söylenebilir. Jeffries' in fotoğrafları binlerce dolara satılmaktadır. Satılan bu fotoğrafların gelirleri evsiz insanların eğitim, rehabilitasyon gibi sorunlarına çözüm bulmada kullanılmakta ve Jeffries sayesinde iş sahibi olup normal Batılı bir yaşama kavuşan kişiler de bulunmaktadır. Bu bağlamda Jeffries sadece olumsuz bir durumu belgelemez; toplumsal yaşamda sanatçı duyarlılı̆̆ ile olumsuz durumu tersine çevirecek eylemlerde de bulunur. Jeffries' in fotoğrafları incelendiğinde bir gerçeği belgeleme aracı olarak öne çıkan fotoğrafın gerçeğin soyut hallerini meydana getirerek insanda duygusal tepkilere yön verdiği söylenebilir. Onun fotoğrafları kapitalist toplumu eleştirme görevini yerine getirmektedir

Sonuç olarak Jeffries fotoğraflarında alt sınıftan insanların duygu durumlarını yaratıı bir sanatsal süreç ile estetik biçimde yansıtır. Sınıfsal çatışmalar onun eserlerinde görünür hale gelir. İdeolojik olarak sanatçının eserleri, kapitalist egemen sistemin karşısında konumlanmaktadır. Fotoğrafı gerçekleştirirken salt bir gerçekliği sunma, yansıtma girişimi içinde değildir. Kendine ait stilizasyonla gerçekliğe etkileyici bir anlam kazandırır. Jeffries 
kapitalist toplumda sanatın para karşılığ mektedir. Eserlerini satarak alt sinif insanların toplumsal yaşamda kendilerini geliştirmeleri için onlara yardımcı da olmaktadır. Diğer yandan fotoğrafın/sanatın kitleleri harekete geçirme işlevinden de yararlanır. Bu doğrultuda, modern dönemde Jeffries'in portre fotoğraflarında ve sanat anlayışında Marksist estetiğin görüşlerine paralel hareket ettiğini söylemek mümkündür. 


\title{
EXTENDED ABSTRACT
}

\section{Relationship between Marxist Aesthetics and Photography from Critical Perspective}

\author{
Rifat Becerikli-Ahmet Dönmez \\ Bozok University- Çankırı Karatekin University
}

The relationship of mankind with nature is based on production and this shapes the notion of nature in human perception. In this context, Marx pointed out that man created an objective world with his/her practice and exhibited a conscious being while processing the inorganic nature. Also, man is a creature that makes a creative production with a purpose in the way that she/he planned. In this sense, the current historical, political and economic conditions affect human production and thus, work of art. Work of art can solely be created in a specific social structure. For example, society should be in the phase of a slave society that they believed to be ruled by gods or semi-gods in order for epics to be created. On the other hand, daily life practices are also significant for artistic production. It can also be said that primitive societies tend to draw cave paintings on the basis of their hunting needs. It seems that sorcery is defined as an art in many primitive communities. The sorcerer is a crucial member of the society in the primitive society that art is named as magic and the artist as sorcerer and a specific system is founded according to him/her in social life. Despite the powerful influence of the sorcerer on society, the expectations are also high. In this context, it is possible to define the artist as a "sorcerer" who tries to find solutions to the problems of social life.

Marx and Engels highlighted that the aesthetic sense of man was not an innate but a socially acquired quality. Marxist aesthetics evidently opposes all views that man has a sense of art from his/her birth; indicates that art skills of man and works of art are created in the flow of historical development. In this respect, aesthetic criteria of man are also a result of current historical and social conditions. Life habits and artistic understanding of primitive societies can be given as an example. Also, Marx and Engels denoted that the aesthetic sense arose during the historical process of human 
labor. In the historical process, man also develops himself/herself in terms of aesthetic values. "If you would like to enjoy art, you should have an art culture," said Marx. Accordingly, it is indicated that aesthetics and art are notions which can be learned and developed in the process.

To Marxist aesthetics, it is important to exhibit the "truth" in life. Natural reality is a reality that exists independently apart from man. On the other hand, aesthetic reality is a reality based on human (artist/subject). To Marxist aesthetics, reality as the object of art is not a reality that does not exist independently apart from man. Also, Marxist aesthetic concludes that art is subjective, but this subjectivity depends on the social and historical formation process. In Marxist aesthetics, the intervention of the artist to objects, people, incidents or situations in nature is essential. On the other hand, it is not a pure fact, but it can be discussed that there is an art created by the artist on an ideological basis. At this point, this does not depend on the artist to produce a copy of the truth, but to reflect his/her work from a specific ideological perspective. For example, work of art is expected to reveal class conflicts in bourgeois society.

Instead of artistic methods, Marx and Engels were opposed to aesthetics, which directly teaches morality, becomes didactic, uses abstract personifications instead of living characters. In other words, it is not preferred that the message of the work appear roughly and directly in front of the reader or the audience. Also, it can be said that the audience and the reader should have a field to understand and interpret the text for the Marxist aesthetic. In the Marxist understanding of art, the artist of work of art should aim for the audience or reader to interpret and act on a social and political basis. The audiences, who judge social problems through art, should then oppose actively or express their reaction to these problems.

Adorno is one of the names who made the most considerable contributions to Marxist aesthetics in the modern period. To him, social reality in the bourgeois system is an incompetent, false and distorted reality. In this case, it is crystal clear that social reality cannot create an example for art. In other words, art cannot have a function such as presenting, revealing or reflecting the social reality. In this respect, the reality created by the art and the artist forms the basis for the progress and development of the social structure. To Adorno, the products of the culture industry are not works of art that turn into commodities; they are fabricated things that have already been manu- 
factured from the very beginning to be sold in the market. In this context, the culture industry aims at entertainment that culture is transformed into entertainment and art into distraction. Adorno denoted that cinema particularly manipulated the audience ideologically.

Walter Benjamin is one of the thinkers who contributed to Marx's understanding of aesthetics. Benjamin denoted that the uniqueness of art disappeared in the modern period, when technical reproduction became prominent. To him, the near perfect reproduction of any work of art with technical tools such as photography and film removes the sorcery of art with its traditional meaning and its aura with modern narration. The loss of the uniqueness and authenticity of the work of art also means a possibility of democratization, in the sense that it is not an aristocratic object of pleasure. He said that art became democratized because it was paved the way for all people to access art, not just kings or the wealthy aristocratic class as in the medieval period. On the other hand, to him, the state of things in a materialized and commodified world loses their symbolic value.

Lee Jeffries implements his task of raising awareness of the masses in the capitalist system by reflecting the photograph with a creative formality and social realistic content. It can be said that the photographer has accomplished the function of thinking and acting on the basis of the audience, especially on the notion of homelessness and the homeless. While doing this, it is revealed that he consciously or unconsciously acted in accordance with specific norms of Marxist aesthetics.

To sum up, Jeffries aesthetically reflects the mood of lower class people through a creative artistic process in his photographs. Class conflicts become visible in his works. Ideologically, his works are against the capitalist dominant system. While taking photos, he is not in an attempt to present or reflect a mere reality. He gives an impressive meaning to reality with his own stylization. Jeffries knows the commodity value of art in capitalist society that is bought and sold for money. He also helps the lower class people to improve themselves in social life by selling his works. On the other hand, he also benefits from the function of photography / art to mobilize the masses. Accordingly, it is possible to say that Jeffries acts in line with the views of Marxist aesthetics in his portrait photography and understanding of art. 


\section{Kaynakça / References}

Adorno, T. (2000). Minima Moralia. (O. Koçak, ve A. Doğukan, Çev.) İstanbul: Metis Yayınları.

Adorno, T. (2002). Aesthetic Theory. London: Continuum.

Akdere, İ. (2010). Marksizimde temel kavramlar. İstanbul: Evrensel basım yayın.

Artan, E. Ç. (2007). Fotoğrafın sanatsal değerinin ötesinde kullanım alanları üzerine bir tartışma: bilgi mi, propaganda mı?,. Cogito dergisi, 52, 88-100.

Bal, M. (2015). Sartre'ın marksist estetik kurama katkıları ve bir marksist estetik bir sanat yapitı olarak seremoni filmi. Felsefelogos, 59, 95-112.

Barret, T. (2012). Fotoğrafi eleştirmek, imgeleri anlamaya giriş. (Y. Harcanoğlu, Çev.) İstanbul: Hayalperest Yayınevi.

Beech, D. (2015). Art and Value-Art's Economic Exceptionalism in Classical, Neoclassical and Marxist Economics. Boston: Brill Press.

Behrens, R. (2011). Adorno sözlü̈̆̈̈u. (M. Tüzel, Çev.) İstanbul: Verus yayınları.

Belge, M. (1989). Marksist estetik-Christopher Caudwell üzerine bir inceleme. İstanbul: Bfs yayınları.

Benjamin, W. (2002). Pasajlar. (A. Cemal, Çev.) İstanbul: Yapı kredi yayınları.

Benjamin, W. (2013). Fotoğrafin Kısa Tarihi. (O. Akınhay, Çev.) İstanbul: Agora Kitaplığ.

Bottomore, T. (1993). Marksist düşs̈nce sözlüğ̈̈̈. (M. Tuncay, Çev.) İstanbul: ந̇letişim Yayınları.

Bozkurt, N. (1995). Sanat ve estetik kuramları. İstanbul: Sarmal yayınevi.

Child Photo Competition. (2018). 08 12, 2020 tarihinde https://childphotocompetition.com/interview-with-lee-jeffries-the-spiritualphotographer/ adresinden alındı

Çalışlar, A. (1990). Önsöz. K. Marx, F. Engels, \& V. Lenin içinde, Sanat ve edebiyat üzerine içinde (s. 11-35). Ankara: Ekim yayınları.

Dellaloğlu, B. F. (2003). Bir giriş- Adorno yüz yaşında. Cogito Dergisi, 36, 13-36.

Demiralp, O. (2007). Tuhaf bir çocuk. Cogito Dergisi, 52, 69-77.

Doğan, M. H. (1975). 100 soruda estetik. İstanbul: Gerçek yayınevi.

Eagleton, T. (2009). Eleştiri ve ideoloji marksist edebiyat teorisi üzerine bir çalışma. (S. Kulıç, Çev.) İstanbul: İletişim yayınları.

Eagleton, T. (2014). Marksizim ve edebiyat eleştirisi. (U. Özmakas, Çev.) İstanbul: İletişim yayınları.

Fischer, E. (1990). Sanatın gerekliliği. (C. Çapan, Çev.) Ankara: İmge kitapevi.

Gombrich, E. H. (2010). Sanatın öyküsü. (Ö. Erduran ve E. Erduran, Çev.) İstanbul: Remzi kitapevi. 
Greatermancunians. (2020). $09 \quad 02, \quad 2020 \quad$ tarihinde https://greatermancunians.blog/2017/07/15/lee-jefferies/ adresinden alınd 1 Güvenç, B. (1979). İnsan ve kültür. İstanbul: Remzi kitapevi. Hauser, A. (1984). Sanatın toplumsal tarihi. (Y. Gölönü, Çev.) İstanbul: Remzi kitapevi. Heinich, N. (2013). Sanat sosyolojisi. (T. Arnas, Çev.) İstanbul: Bağlam Yayıncllı. Horkheimer, M., ve Adorno, T. (2014). Aydınlanmanın diyalektiği. (M. Sezai ve A. Gümüş, Çev.) İstanbul: Kabalcı Yayınevi.

Jay, M. (2001). Adorno. (Ü. Oskay, Çev.) İstanbul: Der yayınları.

Jeffries, L. (2019). 09 02, 2020 tarihinde https://lee-jeffries.co.uk: https://leejeffries.co.uk/lost-angels adresinden alind 1

Julie, A. (2015). Instagrafite. $07 \quad 15, \quad 2020$ tarihinde http://instagrafite.com/?fbclid=IwAR3tzTUruRjJfDv4hU3RRm1MEmASIZIoOf2GI3If8voUSCOyqsNG-f55wU adresinden alind 1

Kellner, D. (2016). Kültürel Marksizm ve kültürel çalışmalar. (F. Tezcan, Der.) Ethos: Felsefe ve Toplumsal Bilimlerde Diyaloglar, 9(2), 132-151.

Kılınç, B. (2008). Yabancılaşmış karakterler ve politik eleştiri: Yavuz Turgul Sinemasından 'Muhsin Bey' örneği. Selçuk İletişim Dergisi, 5(3), 220-235.

King, I. (1991). Laws of Beauty. Aesthetics, Ekonomics, and Materialism in Marx. Sciene E Society, 55(3), 323-335.

Krylov, B. (2009). Önsöz. K. Marx, \& F. Engels, Yazın ve sanat üzerine içinde (s. 11-13). Ankara: Sol yayınları.

Kula, O. B. (2013). Marx Benjamin Adorno sanat ve edebiyat. İstanbul: İş bankası yayinları.

Lomography. (2019). https://www.lomography.com.tr/magazine/146830-tracing-faces-aninterview-with-photographer-lee-jeffries adresinden alınmıştır

Lukacs, G. (1978). Estetik-I. (A. Cemal, Çev.) İstanbul: Payel Yayınevi.

Lukacs, G. (1981). Estetik-II. (A. Cemal, Çev.) İstanbul: Pavel Yayınevi.

Malinowski, B. (1992). Bilimsel bir kültür teorisi. (S. Özkal, Çev.) İstanbul: Kabalc yayınevi.

Malinowski, B. (1998). İkel toplum. (H. Portakal, Çev.) Ankara: Öteki yayınları.

Marcuse, H. (1978). The Aesthetic Dimension- Toward A Critique Of Marxist Aesthetics. Boston: Beacon Press.

Marks, K. (2011). Ekonomi politiŏineleştirisine katkı. (S. Belli, Çev.) Ankara: Sol yayınları. Marks, K. (2013). 1844 El yazmaları. (M. Belge, Çev.) İstanbul: Birikim yayınları.

Marks, K., ve Engels, F. (1990). Sanat ve Edebiyat Üzerine. (A. Çalışlar, Çev.) Ankara: Ekim Yayınları. 
Marks, K., ve Engels, F. (2013). Alman ideolojisi. (T. Ok, ve G. Okay, Çev.) İstanbul: Evrensel basin yayın.

Mollaer, F. (2007). Walter Benjamin'i çağımızda tahayyül etmek. Cogito dergisi, 52, 236265.

Moran, B. (2002). Edebiyat kuramlan ve eleştiri. İstanbul: İetişim yayınları.

Morawski, S. (1970). The aesthetic views of Marx and Engels. The journal of aesthetics and art criticism, 28(3), 301-314.

Örnek, S. V. (1995). 100 Soruda ilkellerde din büyü sanat efsane. İstanbul: Gerçek yayınevi.

Ötgün, C. (2008). Sanat yapitına yaklaşım biçimleri. Sanat ve tasarmm dergisi, 12, 159-178.

Özbek, M. (2000a). Walter Benjamin okumak- I. Ankara üniversitesi SBF dergisi, 55(2), 69-96.

Özbek, M. (2000b). Walter Benjamin okumak- II. Ankara üniversitesi SBF dergisi, 55(3), 103-131.

Pickford, H. W. (2017). Poiêsis, Praxis, Aisthesis : Remarks on Aristotle and Marx S. Gandesha,J.F. Hartle. J. H. Gandesha (Der.), Aesthetic Marx içinde (s. 23-48). London: Bloomsbury Publishing.

Plehanov, G. V. (1967). Sanat ve sosyalizm. (S. Mimoğlu, Çev.) İstanbul: Sosyal yayınları.

Rader, M. (1967). Marx's Interpretation Of Art And Aesthetıc Value. The British Journal of Aesthetics, 7(3), 237-249.

Soykan, O. N. (2003). Adorno ve yapit. Cogito dergisi, 36, 37-64.

Swiderski, E. (1979). Options for a Marxist-Leninist Theory of the Aesthetic. Studies in East European Thought, 20(2), 127-143.

Timuroğlu, V. (2013). Estetik. İstanbul: Berfin yayınları.

Tunalı, İ. (1976). Marxist estetik'te gerçeklik, obje ve subje problemi. Felsefe arkiyi, 20, 99112.

Tunalı, İ. (1993). Marksist Estetik. İstanbul: Altın kitaplar yayınevi.

Tunalı, İ. (1998). Estetik. İstanbul: Remzi kitabevi.

Witte, B. (2002). Walter Benjamin. (M. Tüzel, Çev.) İstanbul: Yapı Kredi Yayınları.

Yacavone, K. (2015). Benjamin Barthes ve fotoğrafin tekilliği. (S. Atay, ve M. Tumen, Çev.) İstanbul: Hayalperest yayınevi.

Yaren, Ö. (2010). Marksist estetik ve snema: erken tartışmalar. Alternatif politika dergisi, 2(2), 106-125.

Yellow Korner. (2017). 08 25, 2020 tarihinde https://www.yellowkorner.com/en/j/leejeffries/\# adresinden alind

Zeytinoğlu, E. (2003). Theodar Adorno'nun sanat tanımı ve protesto. Cogito dergisi (36), 244-255. 
Ziss, A. (1984). Gerçekliği sanatsal özümsemenin bilimi estetik. (Y. Şahan, Çev.) İstanbul: De yayınevi.

\section{Kaynakça Bilgisi / Citation Information}

Becerikli, R. ve Dönmez, A. (2021). Eleştirel perspektiften marksist estetik ve fotoğraf ilişkisi. OPUS-Uluslararası Toplum Araştırmalan Dergisi, 17(36), 3057-3088. DOI: 10.26466/opus.865397 